\title{
The mediating role of e-word of mouth on the relationship between content marketing and green purchase intention
}

\author{
Jassim Ahmad Al-Gasawneh ${ }^{a^{*}}$ and Abdullah Matar Al-Adamat ${ }^{\mathrm{b}}$
}

${ }^{a}$ Department of Marketing, Faculty of Business, Economics and Social Development, Universiti Malaysia Terengganu, Kuala Nerus 21030 Terengganu, Malaysia

${ }^{b}$ Department of Business Administration, Faculty of Economics and administrative sciences, Al al-Bayt University, Mafraq $\neg-25113$, Jordan

\section{CH R O N I C L E}

\section{Article history:}

Received: October 14, 2019

Received in revised format: No-

vember 292019

Accepted: January 15, 2020

Available online:

January 15, 2020

Keywords:

Content Marketing

E-Word of Mouth

Green Purchasing Intention

\section{A B S T R A C T}

The current paper was a quantitative study examining the mediating role of E-WOM when it comes to content marketing and its connection with green purchasing intentions in Jordan. The underpinning theory in this study was the social communication (SC) theory. A survey questionnaire was used to collect relevant data, after being distributed to the general managers. Overall, 202 questionnaires were used in this paper's data analysis, and the outcomes were investigated through partial least squares structural equation modeling. The results of the analysis denoted that the E-WOM controlled the relationship of content marketing with green purchasing intentions. As a result, this paper offers practical findings that companies in Jordan could boost customer intention to purchase green products, by achieving word of mouth and presenting suitable marketing content.

(C) 2020 by the authors; licensee Growing Science, Canada

\section{Introduction}

Due to the worsening worldwide energy crisis and related environmental issues, the consumption of 'green' products has been a topic of great interest to society, both corporate and otherwise. The result is that consumers today have a growing need to find products which are more environmentally friendly (Chen et al., 2015; Goh \& Balaji, 2016). During this search, consumers will look for related information and reviews of specific products before making any purchases. In addition to the traditional avenue of companies presenting advertising messages (Shukor, 2015), word-of-mouth (WOM) is a powerful way of spreading information, which in turn could assist consumers to make their decisions. When occurring on the internet, WOM is known as electronic word-of-mouth (E-WOM). E-WOM can disseminate positive as well as negative statements across the Web, which can be made by future, existing or past consumers of a product or service. In addition, E-WOM allows every consumer to have a voice, and provides them with the ability to share their experiences related to a product or service with people who are socially and geographically diverse (Zhang \& Huang, 2018). During the Internet era, the methods and media of content marketing are much more varied. A prominent feature of online content marketing is that there is a consistent educational aspect, and there are consistently interesting presentations made through the Internet. This means that the cognitive requirements of the intended audience are lowered. Barber (2010) put forward the notion that researchers should look into the purchase intentions of consumers when it comes to green products, and the limited environmental consciousness and sustainability concerns in Jordan are easily noticed. It was considered that Jordan must deal with a number of problems related to sustainable development, and its green initiation is still in its infancy (Alsmadi, 2007; Zu'bi et al, 2015). 
In the work of Rehman and Dost (2013) and Chang (2015) it is stated that viral communication and word of mouth could potential increase insight into green purchase intentions, and boost outlooks on purchasing green products and purchase intentions. Alsmadi (2007) also considered that media comments are powerful communication tools, which have greater capacities to instigate change than traditional practices. Rahim et al. (2016) feel that E-WOM has the ability to affect the psychology or potential consumers at the pre-purchase stage for green products. Also, Majiti (2017) stated that content marketing could positively impact consumer E-WOM. Thus, this paper examines the effects of content marketing when it comes to raising green purchase intentions through EWOM.

\section{Literature review}

\subsection{Content marketing}

Content marketing is sometimes referred to as advertorials, and involves advertisements through articles in a newspaper, magazine, or a website offering information about a product or service (Vinerean, 2017; Wixom \& Todd, 2005). In most cases, brands pay publishers to produce this type of article, and marketers employ this method to share information about a product with their target consumers. Selecting appropriate media allows content marketing to be aimed at a particular group of people. An example of this is seen with content marketing in business newspapers, where a group of people with a clear interest in economics, markets or financial products will be targeted. In the case of brands, storytelling is an efficient way of connecting with target consumers, but this is not the case with traditional print advertising in magazines, newspapers or on websites through banner advertising. Content marketing most often gives a lot of details in its advertisements, and so consumers have a deeper understanding of a product. The actual content is created by advertising agents or the actual firms, in most situations. Content marketing methods and media, due to the widespread use of the Internet, are highly varied. It is common to all online content marketing that there is an educational component, and there is a need to present this content in an interesting way across the Internet, which reduces the cognitive ability needed from the audience. Thus, traditional advertisements are seen as less effective when compared with online content marketing (Sussman \& Siegal, 2003; Bunpis \& Haron 2014; Xiao et al., 2019). In the work of Milhinhos (2015) it was shown that hiding content marketing, an action widely disapproved of, and the independence of news media have allowed people's trust to be earned. Certain content marketing, including blogger and Internet celebrity content, have boosted the perceived value of the fans to the products. Wang and Yang (2014) stated that customers can quickly gain valuable data regarding a product or service through content marketing posted on an e-commerce platform, meaning their shopping efforts are made much easier. In this paper, content marketing perception was evaluated through the work of Xiao et al. (2019), by familiarizing the consumer with the product, describing product benefits, and drawing in customer attention, with the intention being to develop powerful marketing content.

\subsection{Green purchase intention}

Overall, green products are shown to not cause as much harm to the natural environment or to human health as traditional products do. A green product is described as something which produces low pollution, saves on resources, and is recyclable (Speer, 2011). These products are known as ecological or environmentally friendly, and it is often found that these products involve recycling to some degree, less packaging than traditional products, or fewer toxic materials employed in production or packaging. These are all effective steps in limiting any negative effects on the surrounding natural environment. In general, it is considered that these green products are safer for the environment, and examples include green cars (e.g. hybrid cars), recycled products, energy-efficient electronics, organic tea and natural body care products. Purchase intention can be defined as the way a consumer chooses to buy products or services because they feel it fulfils their needs and is in line with their general outlook (Hasan \& Mohammad, 2013). In turn, green purchase intention is described as the likelihood that a person specifically chooses a product with eco-friendly features over other traditional products, within their purchase considerations (Rahim et al, 2016). Green purchase intention is a necessary aspect of the actual green buying behavior of a consumer, and denotes that a customer aims to purchase a green product if it is attractive to them.

\subsection{E-word of mouth}

WOM is where marketing information is shared amongst consumers to the extent that it affects their behavior and attitude regarding a product or service (Huete-Alcocer, 2017). E-WOM costs of informal communication across the Internet aimed at consumers and linked with the usability or key properties of a product or service, or the brand behind them. The benefit of this tool is the fact that every single consumer can be involved, as anyone can share an experience online and post a review of a product for other users to read (Huete-Alcocer, 2017). As social media and digital channels expand, the power of EWOM has also increased exponentially, now having a worldwide influence. EWOM messages are shared rapidly between users across the Internet, and come in the form of online notifications, reviews, opinions and recommendations. These sources offer information for current, past and future consumers of a product or service. Companies also benefit from EWOM, as it allows for easier identification of customer. In addition, EWOM is an inexpensive way of communicating with potential customers. In most cases, EWOM is considered to be a trustworthy and robust source of information (Septiari, 2018). Consumer outlooks, opinions, purchasing decisions and post-use reviews can all be impacted by EWOM evaluation (Al-Debei, 2015). 


\subsection{Research variables}

This paper employed the social communication (SC) theory in order to pinpoint the necessary research variables and research aim, which is described as the actions taken by the communicator to affect the actions of receiver parties (Hovland, 1948). The social communication theory was used in order to develop informative and interesting content marketing, which could then instigate WOM and thus change consumer intentions through purchasing intentions.

\subsubsection{Content marketing and purchase intention}

In the work of Ahmad and Ilkay (2019), the way that content marketing can affect consumers' purchase intention and how this can be controlled by company marketers to stimulate new business in the context of home appliances. Their conclusion was that the content of marketing certainly impacted consumers' purchase intentions. Bunpis and Haron (2014) showed that content marketing positively affected customer purchase intention and boosted awareness. These findings were echoed Milhinhos (2015) who found that content marketing changed the attitudes and purchase intentions of consumers. Based on earlier discussions on the study topic at hand, the following hypothesis is put forward:

$\mathbf{H}_{1}$ : Content marketing has a positive impact on green purchasing intentions.

\subsubsection{Content marketing and E-word of mouth}

In the study by Megan (2017), it was shown that content marketing strongly affected online word-of-mouth. This type of content allows EWOM to thrive through online sharing and discussion regarding a brand and its related products or services. A study by Majiti (2017) found that the overall research model denoted how a trustworthy communication partner was important in high social presence perception, alongside the use of a CHV and an avatar within content marketing. This clearly stimulated consumers' EWOM. Ramzan and Syed (2018) stated that content-based social media marketing was important when constructing customer loyalty and encouraging consumers to share content via EWOM. Therefore, based on earlier discussions, this study puts forward the following hypothesis:

$\mathrm{H}_{2}$ : Content marketing has a positive impact on E-word of mouth.

\subsubsection{E-word of mouth and green purchasing intention}

In the work of Li \& Zhan, (2011), behavior willingness is defined as the intention to act prior to any results being presented, indicative of the consumer's general outlook in this respect. For consumers, the Internet is seen as a way to gather information, which is an important step in their decision process before making a purchase. At the moment, using online platforms allows consumers to share EWOM quickly and across a very large range. In the work of Chang (2015), viral communications were shown to have a clear impact on green purchase intentions. Yan, \& Shah (2018) also showed that EWOM altered Consumer Purchase Intentions in the Fast-Causal Restaurant. Furthermore, Rahim et al (2016) showed that EWOM is critical when it comes to persuading consumer purchasing decisions related to green products. As a result, the current study puts forward the following hypothesis:

H3: E-word of mouth has a positive impact on green purchasing intention.

\subsubsection{E-word of mouth as mediation}

A study by Ngoma and Ntale (2019) showed that WOM was a binding of relationship marketing and customer loyalty. In addition, Septiari (2018) showed that EWOM mediated the relationship between Website Quality and Trust. This is similar to the findings of Rawal and Saavedra (2017) which also showed that word-of-mouth mediated the relationship between prerelease studio actions (stars, production budget, and number of screens). Malik and Hadi (2019) investigated the mediating impacts of EWOM in relation to usefulness and online purchases, and it was shown that EWOM did had a mediating effect. Rahim (2016) analyzed EWOM review adoption of source credibility factors against green purchase intentions, as defined earlier, with similar results. Using the above findings and using the definition of mediator by Baron and Keny (1986), all variables can be used as mediation and can help establish the relationship between an independent variable and dependent variable. Also, this can apply to the link between independent variable and mediation, as well as the relationship between mediation and dependent variables. As a result of the earlier discussions regarding content variables and EWOM, as well as EWOM and green purchase intentions, the current study puts forward the following hypothesis:

$\mathbf{H}_{4}$ : E-word of mouth mediates the relationship between content marketing and green purchasing intention.

\section{Methodology}

This study is descriptive, which is a category of research defined as being able to describe a phenomenon or specific condition, depicting existing situation and allowing for a decision to be made. The basis of this type of research is to confirm a previously developed hypothesis which is related to existing situations. To collect enough suitable data to comprehend green marketing to the greatest extent, the sample of this study needed to consist of people over the age of 22 , because this group of individuals 
are aware of product purchase intentions and are free to make choices from the many available options. A self-administered online questionnaire was shared with citizens of Amman, the capital of Jordan through social media and emails. Amman was chosen since it is the capital of the country and is a busy hub of people and businesses. The questionnaire was made up of 15 questions, separated into three sections. The first section was related to the independent variable (content marketing), the second section was about the mediator variable (electronic word of mouth) and dependent variable (green purchase intention), while in section 3, participants were queries socio-demographic characteristics. There were 5 Likert scales used in the questionnaire, to help establish accurate results. There were two key actions taken to ensure the validity and reliability of the questionnaire. Firstly, the survey was sent to academic experts (professors at universities) in order to receive feedback and make recommended changes. The second action was to test the internal consistency using the Cronbach alpha for the variables, which were content marketing 0.83 ; electronic word of mouth 0.74 ; and green purchase intention 0.73 . After following these two actions, the instrument was confirmed as valid and reliable. The sample size is suggested to be in line with the power of analysis, which is the minimum number of samples based on the model's complexity. Following Green's (1991) table and using 2 predictors from the research framework at medium effect size as suggested by Gefen et al. (2011), the minimum sample size for this paper was set as 74 . The study by Hair (2010) suggests that, in order to gather accurate results, the sample size needs to exceed 100, which means that 300 questionnaires needed to be distributed overall. In Table 1, the study variables, item numbers and sources of adapted scales are shown. For the analysis of research data, PLS-SEM software was used.

Table 1

scales Used in Research

\begin{tabular}{llll}
\hline No & Variable & No of items & Reference \\
\hline 1 & content marketing (CM) & 5 & Xiao et al (2019) \\
2 & electronic word of mouth (E-WOM) & 5 & Septiari (2018); Al-Debei (2015) \\
3 & green purchase intention (GPI) & 5 & Rahim et al (2016) \\
\hline
\end{tabular}

\section{Results}

A total of 215 questionnaires were returned, with 13 questionnaires needing to be excluded because they were incomplete, leaving 202 usable questionnaires.

\subsection{CFA Model for Research Model}

In order to measure the 3 first-order constructs in (CM, E-WOM, GPI), 18 items were used. In the evaluation of the measurement model of the research model, the study used the confirmatory factor analysis. In Fig. 1, the measurement model is presented.

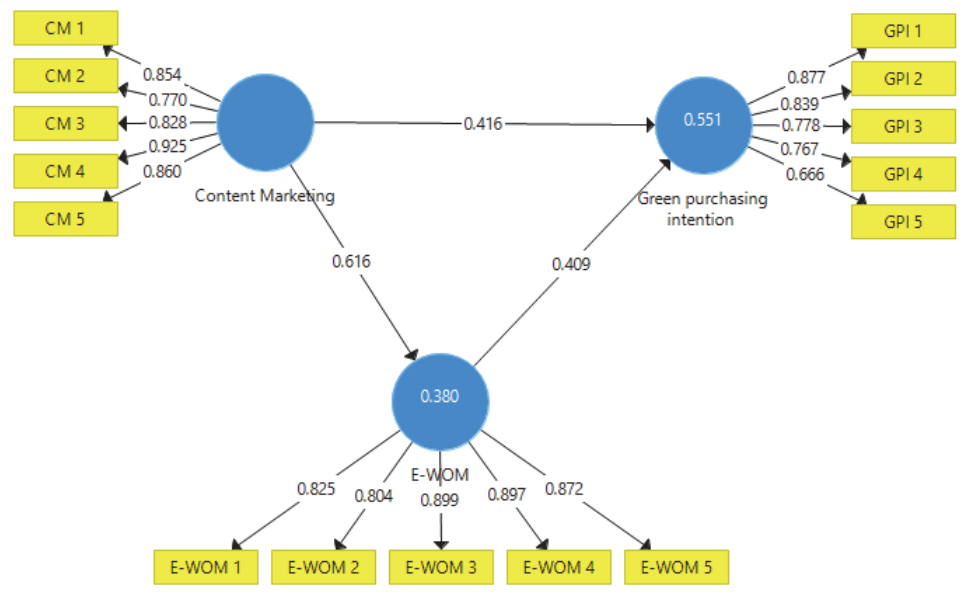

Fig. 1. The measurement model

\subsubsection{Convergent Validity}

In Table 2, the confirmatory factor analysis for the measurement's models are seen. Also, the evaluation results of the standardized factor loadings of the model items can be seen. These show that the standardized factor loadings were all above 0.6 , with loadings ranging from 0. 666 to 0.925 . In addition, the values of AVE for all constructs were between 0.622 and 0.740 . The cut-off value was 0.5 based on the work of Hair et al. (2010), and all values were above this level. The values of composite reliability for all constructs were between 0.891 and 0.934 , with these obtained values all being above the suggested value of 0.7 for all constructs, as defined in (Hair et al., 2010; Fornell \& Larcker, 1981). 
Table 2

The Result of Cronbach's Alpha and Convergent Validity for the CFA Model on the Research Model

\begin{tabular}{lllll}
\hline Construct & Items & Factor loading & CR & AVE \\
\hline CM & CM 1 & 0.854 & 0.928 & 0.721 \\
& CM 2 & 0.77 & & \\
& CM 3 & 0.828 & & \\
& CM 4 & 0.925 & & 0.740 \\
\hline E-WOM & CM5 & 0.860 & 0.934 & \\
& E-WOM 1 & 0.825 & & \\
& E-WOM2 & 0.804 & & \\
& E-WOM 3 & 0.899 & & \\
& E-WOM 4 & 0.897 & & \\
\hline GPI & E-WOM 5 & 0.872 & & \\
& GPI 1 & 0.877 & & \\
& GPI 2 & 0.839 & & \\
\end{tabular}

\subsection{Discriminant validity}

The current study collected HTMT in order to establish the discriminant validity for the model as described in (Henseler, 2015).

Table 3

The HTMT for constructs

\begin{tabular}{lccc}
\hline & CM & E-WOM & GPI \\
\hline CM & & & \\
E-WOM & 0.641 & & \\
GPI & 0.733 & 0.739 & \\
\hline
\end{tabular}

Table 3 shows that all HTMT values of the constructs were under 0.90, being between 0.641 and 0.739 . As a result, it is clear that every latent construct measurement was entirely discriminant against each other (Henseler et al., 2015). After investigating the convergent validity and discriminant validity of the measurement model, it is considered that the measurement scale used to evaluate the constructs and their relative items in the CFA model was fully reliable and valid.

\subsection{Hypothesized Direct Effects of the Constructs in Structural Model}

Table 4

Hypothesized Direct Effects Structural Model

\begin{tabular}{ccccccccc}
\hline Path & St, $\beta$ & St. d & $\mathrm{R}^{2}$ & $\mathrm{Q}^{2}$ & $\mathrm{~F}^{2}$ & VIF & T-value & P-value \\
\hline $\mathrm{CM} \rightarrow$ GPI & 0.416 & 0.155 & 0.551 & 0.301 & 0.239 & 1.612 & 2.690 & 0.007 \\
$\mathrm{E}-\mathrm{WOM} \rightarrow$ GPI & 0.409 & 0.163 & & 0.231 & 1.856 & 2.514 & 0.012 \\
$\mathrm{CM} \rightarrow$ E-WOM & 0.616 & 0.090 & 0.380 & & 0.612 & 1 & 6.816 & 0.000 \\
\hline
\end{tabular}

In Table 4, the values of $\mathrm{R}^{2}$ for GPI, E-WOM are seen, which are 0.551 and 0.380 respectively. This shows that $55.1 \%$ of variations in GPI are made clear by the predictors (CM, E-WOM), while 38\% of variations in E-WOM are made clear by their predictors $(\mathrm{CM})$. The $\mathrm{R}^{2}$ values meet the 0.19 cut off value, as suggested in the work of (Chin, 1998). The $\mathrm{Q}^{2}$ value for GPI of 0.301 was much higher than zero, denoting that there is a predictive relevance to the model analogous to the suggestions of (Chin, 2010; Cheung et al., 2010). The model shows a sufficient level of fit and substantial predictive relevance. Also, the VIF values were 1.612, 2.514 and 1, all of which were less than 5 (Hair et al., 2014). For predicting GPI, the p-value of CM and E-WOM were 0.007 and 0.012 respectively. For E-WOM predictive factors, the p-value of CM was 0.000 , denoting that the chance of achieving prediction through absolute p-values are 0.01 and 0.05 . Also, the path coefficient $(\mathrm{S}, \mathrm{B})$ values for (CM to GPI), (E-WOM to GPI), and CM to E-WOM were $0.416,0.409$ and 0.616 respectively. This shows that the relationships are positive, and hypotheses $\mathrm{H} 1, \mathrm{H} 2, \mathrm{H} 3$ are supported.

\subsection{Indirect effect of the constructs}

Table 5 shows the outcomes of the bootstrapping, which show that the indirect effect of CM on GPI through E-WOM was positive and statistically significant at the 0.05 level; $\beta=0.252$, T-value $=2.154$, P-value $=0.030$. The indirect effect of Boot CI Bias Corrected did not straddle a 0 in between, meaning that a mediation effect would be in place (Preacher \& Hayes, $2004,2008) ; \mathrm{LL}=0.033$, UL $=0.542$. The results showed that the mediation effect was statistically significant, and so hypothesis $\mathrm{H} 4$ was supported. 
Table 5

Results of Hypotheses Testing for the Mediation

\begin{tabular}{ccccccc}
\hline PATH SHAPE & St. $\beta$ & St. d & T values & $2.50 \%$ & $97.50 \%$ & p-values \\
\hline $\mathrm{CM} \rightarrow$ E-WOM $\rightarrow$ GPI & 0.252 & 0.117 & 2.154 & 0.033 & 0.542 \\
\hline
\end{tabular}

\section{Discussion and Conclusion}

Continuing the work of earlier studies into the world of content marketing, EWOM and purchasing intentions, and the relationship of content marketing and consumer purchase intentions, the current study has supported hypotheses were analogous to the results of Yaqubi and Karaduman (2019). Specifically, effective and appropriate content marketing encourages consumers in their green purchasing intentions. Also, similar to Ramzan and Syed (2018) regarding the importance of contentbased social media marketing when it comes to motivating consumers to share content through EWOM, the current study's $\mathrm{H}_{2}$ result showed that content marketing had a positive impact on EWOM. Thus, it can be said that effective and clear content marketing encourages online users or customers to undertake EWOM with their peers. By supporting $\mathrm{H}_{3}$, this study was in line with that of Rahim et al. (2016), where the effect of EWOM on GPI was positive. This allowed the current study to confirm that EWOM is a valuable part of drawing in consumers to purchase green products. This paper offers valuable contributions with its use of social communication (SC) theory to analyze E-WOM as a mediator between content marketing and green purchasing intentions. The findings were additionally examined through the PLS 3 software suite. Lastly, hypothesis $\mathrm{H}_{4}$ was supported in this study, under which EWOM was shown to mediate the relationship between content marketing and green purchasing intentions. This denotes that clear and effective content marketing, involving suitably alluring content, can strongly encourage satisfied customers to share their positive experiences through EWOM, which in turn increases the interest of other customers towards green products.

\section{Future research}

This paper examined customers in Jordan, and on a smaller scale, companies can use these same approaches for their own customers. Future studies could confirm if other variables could be used to control the relationship between E-WOM and green purchasing intentions. As this study used a quantitative methodology, future studies could instead use the mixed methods approach for potentially superior insights.

\section{Acknowledgement}

The authors would like to thank the anonymous referees for constructive comments on earlier version of this paper.

\section{References}

Ahmad, Y.Y, \& Ilkay, K. (2019) The impact of content marketing on consumers' purchase intention for home appliances: A study in Afghanistan. International Journal of Business and Management Invention (IJBMI), 2319, 38-47.

Al-Debei, M. M., Akroush, M. N., \& Ashouri, M. I. (2015). Consumer attitudes towards online shopping: the effects of trust, perceived benefits and perceived web quality. Internet Research, 25(5), 707-733.

Alsmadi, S. (2007). Green marketing and the concern over the environment: measuring environmental consciousness of Jordanian consumers. Journal of Promotion Management, 13(3-4), 339-361.

Barber, N. (2010). "Green” wine packaging: targeting environmental consumers. International Journal of Wine Business Research, 22(4), 423-444.

Baron, R. M., \& Kenny, D. A. (1986). The moderator-mediator variable distinction in social psychological research: Conceptual, strategic, and statistical considerations. Journal of Personality and Social Psychology, 51(6), 1173.

Bunpis, L., \& Haron, M. S. (2014). The influence of content marketing on customer brand engagement towards online herbal cosmetic store in Thailand.

Chang, S. H. (2015). The influence of green viral communications on green purchase intentions: The mediating role of consumers' susceptibility to interpersonal influences. Sustainability, 7(5), 4829-4849.

Chen, Y. S., Chang, C. H., Yeh, S. L., \& Cheng, H. I. (2015). Green shared vision and green creativity: The mediation roles of green mindfulness and green self-efficacy. Quality \& Quantity, 49(3), 1169-1184.

Cheung, C. M., \& Thadani, D. R. (2010). The Effectiveness of Electronic Word-of-Mouth Communication: A Literature Analysis. Bled conference, 23, 329-345.

Chin, W. W. (1998). Commentary: Issues and opinion on structural equation modelling.

Chin, W. W. (2010). How to write up and report PLS analyses In V. Vinzi, W.W. Chin, J. Henseler, \& H. Wang (Eds.), Handbook of partial least squares (pp.655-690). New York: Springer

Fornell, C., \& Larcker, D.F. (1981). Evaluating structural equation models with unobservable variables and measurement error. Journal of Marketing Research, 18(1), 39-50.

Gefen, D., Rigdon, E. E., \& Straub, D. (2011). Editor's comments: an update and extension to SEM guidelines for administrative and social science research. MIS Quarterly, 35(2), 3-14.

Goh, S. K., \& Balaji, M. S. (2016). Linking green scepticism to green purchase behaviour. Journal of Cleaner Production, 131, 629-638. 
Green, S. B. (1991). How many subjects does it take to do a regression analysis. Multivariate behavioral research, 26(3), 499-510.

Hair, J. F., Hult, G. T. M., Ringle, C., \& Sarstedt, M. (2014). A primer on partial least squares structural equation modelling (PLS-SEM). Washington, DC: Sage Publications

Hasan, S., Ali, M., \& Mohammad Javad, S. (2013). Iranian consumers' purchase intention toward global brands. Interdisciplinary Journal of Contemporary Research in Business, 8, 361-371.

Henseler, J., Ringle, C. M., \& Sarstedt, M. (2015). A new criterion for assessing discriminant validity in variance-based structural equation modeling. Journal of the Academy of Marketing Science, 43(1), 115-135.

Hovland, C. I. (1948). Social communication. Proceedings of the American Philosophical Society, 92(5), 371-375.

Huete-Alcocer, N. (2017). A literature review of word of mouth and electronic word of mouth: Implications for consumer behaviour. Frontiers in psychology, 8, 1256.

Li, J., \& Zhan, L. (2011). Online persuasion: How the written word drives WOM: Evidence from consumer-generated product reviews. Journal of Advertising Research, 51(1), 239-257.

Lim, W. M. (2015). Antecedents and consequences of e-shopping: an integrated model. Internet Research 25(2), 184-217

Luo, C., Luo, X. R., Schatzberg, L., \& Sia, C. L. (2013). Impact of informational factors on online recommendation credibility: The moderating role of source credibility. Decision Support Systems, 56, 92-102.

Majiti, A. (2017). Content marketing.

Malik, I. A., \& Hadi, N. U. (2019). Inspirational factors of electronic word of mouth: A case of social networking sites. Journal of Managerial Sciences, 13(2).

Megan, M. (2017, Jun 25). Why is Word of Mouth Marketing so Important? Retrieved from Https://www.social media today.com/marketing/why-word-mouth-marketing-so-important

Milhinhos, P. R. V. (2015). The impact of content marketing on attitudes and purchase intentions of online shoppers: the case videos \& tutorials and user-generated content (Doctoral dissertation).

Ngoma, M., \& Ntale, P. D. (2019). Word of mouth communication: A mediator of relationship marketing and customer loyalty. Cogent Business \& Management, 6(1), 1580123.

Preacher, K. J., \& Hayes, A. F. (2008). Asymptotic and resampling strategies for assessing and comparing indirect effects in multiple mediator models. Behaviour Research Methods, 40(3), 879-891

Rahim, R. A., Sulaiman, Z., Chin, T. A., Baharun, R., \& Muharam, F. M. (2016). Measuring electronic word of mouth review adoption on green purchase intention using source credibility theory. Advanced Science Letters, 22(12), $4283-4287$.

Rahim, R. A., Sulaiman, Z., Chin, T. A., Zaidin, N., \& Zakuan, N. (2015). E-WOM review adoption and green purchase intention: The application of source credibility theory (SCT). Advanced Science Letters, 21(6), 2150-2154.

Ramzan, U., \& Syed, A. R. (2018). Role of content-based social media marketing in building customer loyalty and motivating consumers to forward content. Journal of Internet Banking and Commerce, 23(3), 1-20.

Rawal, M., \& Saavedra, J. L. (2017). Mediating effect of word-of-mouth in the movie theatre industry. Journal of Media and Communication Studies, 9(3), 17-23.

Rehman, Z. U., \& Dost, M. B. (2013, June). Conceptualizing green purchase intention in emerging markets: An empirical analysis on Pakistan. The 2013 WEI International Academic Conference Proceedings (pp. 99-120).

Septiari, E. D. (2018). The Effect of eWOM as Mediation of Website Quality and Trust.

Shukor, M. S., Sulaiman, Z., Thoo, A. C., \& Zakuan, N. (2015). The effect of emotional versus rational appeal in advertising on Malaysian consumers' purchase intention of hybrid car. Applied Mechanics and Materials.

Speer, M. (2011). What is a green product. sustainable Earth. Retrieved on 5th March 2014.

Sussman, S. W., \& Siegal, W. S. (2003). Informational influence in organizations: An integrated approach to knowledge adoption. Information Systems Research, 14(1), 47-65.

Vinerean, S. (2017). Content Marketing Strategy. Definition, Objectives and Tactics. Expert Journal of Marketing, 5(2).

Wang, X., \& Yang, J. (2014). The joint effect of advertorial and print Ad. China Soft Sci, 5, 100-109.

Wixom, B. H., \& Todd, P. A. (2005). A theoretical integration of user satisfaction and technology acceptance. Information Systems Research, 16(1), 85-102.

Xiao, L., Guo, F., Yu, F., \& Liu, S. (2019). The effects of online shopping context cues on consumers' purchase intention for cross-border e-vommerce sustainability. Sustainability, 11(10), 2777.

Yan, X., Shah, A. M., Zhai, L., Khan, S., \& Shah, S. A. A. (2018, January). Impact of Mobile Electronic Word of Mouth (EWOM) on Consumers Purchases Intentions in the Fast-Causal Restaurant Industry in Indonesia. In Proceedings of the 51st Hawaii International Conference on System Sciences.

Zhang, L., Li, D., Cao, C., \& Huang, S. (2018). The influence of greenwashing perception on green purchasing intentions: The mediating role of green word-of-mouth and the moderating role of green concern. Journal of Cleaner Production, 187, 740-750.

Zu'bi, M. F., Al-Dmour, H., Al-Shami, M., \& Nimri, R. (2015). Integrated Green Purchase Model: An Empirical Analysis on Jordan. Management, 4(2), 139-151. 
(C) 2020 by the authors; licensee Growing Science, Canada. This is an open access article distributed under the terms and conditions of the Creative Commons Attribution (CC-BY) license (http://creativecommons.org/licenses/by/4.0/). 